\title{
ГРЕЧЕСКИЙ ПОХОД СТИЛИХОНА 397 ГОДА В КОНТЕКСТЕ ПРОТИВОСТОЯНИЯ С ЕВТРОПИЕМ И АЛАРИХОМ
}

\section{THE GREEK CAMPAIGN OF STILICHO IN 397 IN THE CONTEXT \\ OF THE CONFRONTATION WITH EUTROPIUS AND ALARIC}

S. Yartsev

Summary: The article is devoted to the military campaign of the de facto ruler of the western part of the Roman Empire, Stilicho, in Greece in 397. Relying on a wide range of sources, the author considers these events in the context of a complex tangle of contradictions in the Stilicho Alaric - Eutropius triangle. According to the author, the reason for the Greek campaign of Stilicho in 397 was the active opposition to his farreaching plans to seize power in the state, the de facto ruler of the eastern part of the Roman Empire, Eutropius. The main provoking factor of this campaign was the information that reached the West, both about the agreement reached by Eutropius with Alaric, and about the permission received by the Goths to settle in Illyricum. This completely destroyed the Stilicho's plans and made a military solution to the impending conflict inevitable. At the same time, the invasion into Greece was carried out under the pretext of protecting it from the allegedly attacking Goths. In fact, the main goal of Stilicho's military campaign in Greece was to return the Goths to their command, as well as to remove a powerful eunuch from power in the East. Thus, the de facto ruler of the West once again had a chance to achieve his ambitious claim to power over both parts of the Roman Empire. However, the military actions of Stilicho against Alaric, which began in Greece, again aroused the active opposition of Eutropius. He urgently obtained from the Emperor Arcadius an order for Stilicho to return immediately to his home in the West, and in case he decided to go to Constantinople, he also declared him an enemy of the state. Despite the fact that the struggle between Stilicho and Eutropius did not end there, it is obvious that it was a categorical order from Constantinople, as in the recent past, that again deprived Stilicho of victory and any prospects for his further stay in the East.

Keywords: Roman Empire, Greece, Stilicho, Eutropius, Alaric, Goths, Huns.
Ярцев Сергей Владимирович

Д.и.н., доцент, Тульский государственный педагогический университет им Л.Н. Толстого

s-yartsev@yandex.ru

Аннотация: Статья посвящена военной кампании фактического правителя западной части Римской империи Стилихона в Греции в 397 году. Опираясь на широкий круг источников, автор рассматривает данные события в контексте сложного клубка противоречий в треугольнике Стилихон - Аларих - Евтропий. По мнению автора, причиной греческого похода Стилихона в 397 г. стало активное противодействие его далеко идущим планам по захвату власти в государстве, фактического правителя восточной части Римской империи Евтропия. Главным же провоцирующим фактором данного похода, стала дошедшая до Запада информация, как 0 достигнутом соглашении Евтропия с Аларихом, так и о полученном готами разрешении на расселении в Иллирике. Это полностью разрушало замыслы Стилихона и делало военное решение назревшего конфликта неизбежным. При этом вторжение в Грецию было совершено под предлогом ее защиты от якобы напавших на нее готов. На самом деле главной целью военной кампании Стилихона в Греции, являлось возвращение готов под свое командование, а также устранение от власти на Востоке могущественного евнуха. Таким образом, у фактического правителя Запада, вновь появлялся шанс достичь своих амбициозных притязаний на власть над обеими частями Римской империи. Однако начавшиеся в Греции военные действия Стилихона против Алариха, вновь вызвали активное противодействие Евтропия. Он срочно добился от императора Аркадия издания приказа Стилихону о его немедленном возвращении домой на Запад, а на случай, если же он надумает отправиться в Константинополь, объявил его еще и врагом государства. Несмотря на то, что борьба между Стилихоном и Евтропием на этом не закончилась, очевидно, что именно категорический приказ из Константинополя, как и в недалеком прошлом, вновь лишил Стилихона победы и всяких перспектив его дальнейшего пребывания на Востоке.

Ключевые слова: Римская империя, Греция, Стилихон, Евтропий, Аларих, готы, гунны.
$\mathrm{H}$ е вызывает сомнений, что после убийства Руфина, многие в империи были уверены, что Стилихон окончательно победил и в ближайшее время римский мир ждет новое объединение под властью этого могущественного правителя Запада. Такой проект, разумеется, выглядел далеко не безрассудным и имел свое рациональное зерно, хотя и вызывал вопросы по поводу предполагавшегося кондоминиума с ведущей ролью Запада в объединенном государстве [28, р. 363, 416]. В любом случае, на такой оптимистический настрой фактический правитель Запада имел все основания, так как именно теперь близкие к нему люди находились во главе восточной римской армии в Константинополе и, следовательно, должны были подчиняться его приказам. Однако сменивший Руфина, препозит священной опочивальни евнух Евтропий, очень быстро смог изменить ситуацию в свою пользу и превратиться в куда более опасного противника Стилихона, чем упомянутый бывший фаворит императора Аркадия. Развернувшаяся борьба между Стилихоном и Евтропием вновь обострила отношения между Западом и Востоком, став предвестником новых серьезных катаклизмов в государстве. Кульмина- 
цией событий этого очередного витка противостояния двух центров власти в государстве, стал поход Стилихона на Грецию в 397 году, о причинах и обстоятельствах которого научные споры продолжаются до сих пор. При этом наиболее сложной проблемой дискуссии, является характер взаимоотношений между тремя основными действующими лицами римской истории данного времени - Стилихоном, Евтропием и Аларихом [2; 4; 6; 7; $8 ; 13 ; 14 ; 15 ; 20 ; 23 ; 28 ; 33 ; 38]$. Отсутствие единой точки зрения по данному вопросу, не позволяет восстановить объективную картину одного из самых острых моментов борьбы за власть в государстве в конце IV в. и требует еще раз вернуться к комплексному анализу источников этого сложного времени.

Начнем с того, что важным фактом для понимания сложившейся ситуации после смерти Руфина, необходимо считать отправку довольно мирного посольства из Константинополя в Милан зимой 395/396 г. Считается, что на этих переговорах было достигнуто официальное соглашение о передаче Паннонии, Норика и Далмации от Востока к Западу. При этом остальная часть Иллирика продолжала оставаться за Константинополем [15, с. 141145]. В такой традиционной интерпретации событий несколько смущает то обстоятельство, что назначение Стилихоном своего человека на должность преторианского префекта Иллирика произошло только через год после передачи ему вышеупомянутых территорий (Cod. Th., 11.16.21), и следовательно, должно иметь, какие-то объяснения. Но даже в этом случае, можно согласиться с Йеном Хьюджесом, что факт таких переговоров, начавшихся буквально сразу же после убийства Руфина и вступления в его должность Евтропия, больше свидетельствует о попытке препозита священной опочивальни откупиться от Стилихона территориальными уступками. Другими словами, возвращением стратегической для Стилихона территории, Евтропий надеялся, что последний забудет о своих экспансионистских замыслах по поводу восточной части государства [15, с. 143].

Однако, будучи человеком, хорошо осведомленным с планами Стилихона, Евтропий вряд ли мог рассчитывать на то, что всесильный властитель Запада так легко откажется от своих претензий на parens principum над всей империей. Поэтому справедливей будет считать, что указанные переговоры больше предназначались для прикрытия других важных действий всесильного евнуха по упрочнению своей власти и усилению влияния на императора Аркадия (Eunap., 66, 69, 74; Zosim., V, $8 ; 11,1 ; 12,1)$. Дело в том, что Евтропий, помня судьбу Руфина, не мог не понимать, от кого ему теперь реально стала исходить смертельная опасность. Именно поэтому все последующие предпринятые шаги нового фаворита Аркадия, безусловно, в той или иной степени, были продиктованы, в первую очередь, стремлением обеспечить себе защиту от притязаний Стилихона.
Скорее всего, именно данным противостоянием были обусловлены действия Евтропия по избавлению от феодосианцев в восточной армии, которые безжалостно, под предлогом различных причин, смещались со своих постов и отправлялись в ссылку [5, с. 91]. «Без какой-либо причины он составил заговор даже против Тимасия, который был магистром во времена Валента и принимал участие во множестве войн» (Zosim., V, 8, 3). Был лишен имущества и высоких чинов даже сам Абунданций, который «находился на военной службе со времен Грациана, достиг великих почестей при Феодосии и был теперь магистром и получил консульское достоинство» (Zosim., V, 10, 5). Неоднозначность последней ситуации заключалась в том, что Евтропий был лично обязан Абунданцию, так как возвысился благодаря именно его покровительству (Claud.Eutrop., I, 154-170) [3, с. 212, прим. 3]. Поэтому такие действия Евтропия можно оправдать только смертельной опасностью и, следовательно, необходимостью срочного перехода восточных войск под свое командование. Тем самым у Евтропия появлялась возможность предотвратить вероятность объединения Стилихоном военной власти над всеми вооруженными силами Римской империи [18, s. 639]. В пользу этого свидетельствует и тот факт, что фактически все пострадавшие являлись союзниками всесильного властителя Запада [15, с. 153], не говоря уже о Гайне, который и не скрывал, что являлся человеком Стилихона. Однако теперь даже сам он убийца Руфина, не продвигался по службе, фактически был отдален от армии и лишен вакантных военных должностей [5, с. 91].

Все вышесказанное, действительно свидетельствует в пользу версии о главнейшей стратегической цели Евтропия, как можно быстрее лично возглавить командование восточно-римскими войсками. Однако если это так, то Евтропий, в первую очередь, должен был вернуть под свой контроль готов Алариха, как самую боеспособную силу Востока, способную противостоять западной армии Стилихона. Мнение, что Евтропий в это время не интересовался готами, занимаясь проблемами укрепления собственной власти и поэтому слишком поздно вышел на Алариха [15, с. 146; 8, с. 56], выглядит неубедительно. По сути дела судьба Евтропия в наибольшей степени зависела от того, на чью сторону перейдет Аларих, поэтому медлить с переговорами здесь было нельзя. Конечно Стилихон в сложившейся ситуации, мало, что мог предложить Алариху (Claud. De bell. Got., 566-567; Oros., VII, 37, 2) [27, р. 172; 45, р. 122], тем более что конфликт между ними, по всей вероятности достиг своего апогея и исключал возможность быстрого преодоления. Аларих, как известно, хотел не только высокую должность в римской армии, но и новые территории для расселения готских федератов. Это шло в разрез с планами могущественного правителя Запада, который, судя по всему, хотел вернуть готов во Фракию под главенство регионального магистра Гайны и, по-видимому, каким-то образом, 
избавиться от самого Алариха. Однако мы не можем исключить и вероятность того, что Стилихон мог радикально пересмотреть свои планы по отношению к Алариху в связи с изменившимся раскладом противоборствующих сил в государстве. В данной ситуации Евтропий не мог безучастно ждать, когда Стилихон победит готов и договорится с Аларихом. Он прекрасно понимал, что переход готов на сторону Стилихона, обернется для него самой настоящей катастрофой. Разумеется, последний также хорошо понимал о значении готского фактора в начавшейся очередной схватке за власть. Поэтому задачей Стилихона было, наоборот, всеми возможными способами не допустить заключение нового договора Евтропия с Аларихом. При этом рассчитывать в этом деле, Стилихон мог только на помощь своих людей и союзников, занимающих командные посты в восточно-римской армии. Не исключено, что именно данное обстоятельство являлось главным фактором, из-за которого Евтропий был вынужден ускорить свои действия по смещению с командных должностей людей Стилихона. Вероятно, данные высокопоставленные военные делали все от них зависящее, чтобы не дать соединиться Алариху и Евтропию, тем самым лишив последнего независимой от них защиты. Таким образом, вряд ли восточно-римское правительство решило вступить в переговоры с Аларихом только после того, как с ним не справился Стилихон [17, с. 34]. Похоже, что данные переговоры от лица Евтропия, несмотря на серьезное противодействие внутренней оппозиции и других, откровенно враждебно ему сил, начались сразу же после возвышения могущественного евнуха, так как от этого напрямую зависела его жизнь.

Существует косвенное свидетельство, указывающее на то, что практически сразу после смерти Руфина, Аларих установил контакт с Евтропием, возможно даже заключив с ним, какое-то предварительное соглашение. Здесь надо исходить из того, что после гибели Руфина действие договора с готами аннулировалось, а варвары вновь превращались в мятежников [4, с. 203]. Но тогда они, не смогли бы беспрепятственно пройти через Фермопилы - довольно серьезное естественное препятствие на единственной дороге из Фессалии в Среднюю Грецию [20, р. 43]. Тем не менее, по словам Зосима, Аларих «на подступах к Фермопилам ... тайно отправил гонца к проконсулу Антиоху и начальнику гарнизона Фермопил Геронтию, чтобы известить о своем приближении. После этого проход был открыт из-за ухода основных частей, державших оборону» (Zosim., V, 5,5). Конечно, самое простое в данной ситуации, это довериться словам 3осима и допустить реальную малочисленность римского гарнизона, по причине которой готы и были пропущены через горный проход [15, с. 146-147]. Однако это плохо согласуется с тем, что Фермопилы с успехом можно было оборонять даже малыми силами, как уже бывало в истории указанной местности. Данное обстоятельство явно указывает на то, что беспрепятственный путь варваров в
Грецию, скорее всего, был обеспечен союзным статусом готов Алариха, явно прошедшим Фермопилы в качестве федератов [20, р. 43]. В этом случае, римских командиров действительно сложно заподозрить в государственной измене [4, с. 203].

Более того, такой вариант пускай косвенно, но все же подтверждает Евнапий, который сохранил сведения, что вместе с варварами через горный проход прошли и некие «люди, одетые в черные мантии» (Eunap. VS., VII, 32). Видимо это были монахи, следующие вместе с армией федератов с целью разрушения языческих храмов, в точном соответствии с пророчеством иерофанта Элевсинского о разрушении храмов и прекращении почитания древних богинь (Eunap. VS., VII, 32). К сожалению, идентифицировать данных монахов, до сих пор не удается. Мнение о них, как о фракийцах в черных одеждах [36, р. 69-72], не нашло поддержки среди ученых [44, p. 171-176]. Не исключено, что перед нами полностью придуманный Евнапием рассказ с целью обвинения христиан в разрушении и запустении языческих храмов. Тем более что у Зосима данная информация отсутствует, хотя в своей истории он, как правило, следует за Евнапием [29, р. 85; 20, р. 44]. Но если все же допустить, что монахи действительно сопровождали Алариха во время перехода его в Грецию, то готов будет очень трудно представить врагами римского мира, грабителями и убийцами мирных греков. Хотя конечно версию перехода Алариха в Грецию с целью перехвата Стилихона по просьбе Евтропия [24, р.158], необходимо полностью исключить. В 396 г. новый фаворит императора Аркадия не мог знать о планах западного правителя о походе в Грецию, да и готов, как провоцирующего к войне фактора, там еще не было.

Невероятной выглядит и точка зрения о наличии у Алариха коварного плана грабежа Греции, следуя которому он умышленно прошел Фермопилы в качестве федерата [4, с. 203]. Казалось бы, это подтверждает тот же Зосим, ведь, по его словам, готы в Греции «принялись грабить сельское население и совершенно разорили города, убивая мужчин всех возрастов и захватывая женщин и детей, сгоняя их в толпы, подобно стадам. Там же и все имущество, взятое в качестве добычи, собиралось ими вместе. Всю Беотию и другие области Греции варвары прошли насквозь после того, как они проникли в Грецию через Фермопилы, и так опустошили их, что само их имя стало символом разрушений и погромов этих дней» (Zosim., V, 5, 6-7). Тем не менее, тот же Зосим недвусмысленно отмечает, что «Фивы избежали общей участи, отчасти из-за крепости стен, а отчасти потому, что Аларих не имел терпения, необходимого для долгой осады», а также в связи с тем, что варвары стремились к Афинам (Zosim., V, 5, 7). Однако Афины также не были разграблены, ведь знаменитый город, по словам Зосима, довольно успешно защищали языческие боги (Zosim., V, 5, 7). 
Правда, здесь выясняется, что Аларих находясь в Афинах, почему-то не настроен был вообще кого-то грабить и зачем-то решил послать грекам «вестников заключить мир. После определения условий договора и обмена клятвами Аларих вошел в Афины лишь с несколькими спутниками. Он обратился к афинянам со всей доброжелательностью и после омовения принял дары от избранных граждан, а также вручил свои. После этого он покинул город и вся Аттика осталась невредимой» (Zosim., V, $6,2)$. В дальнейшем готы, опять же с разрешения римлян, спокойно перешли перешеек между Средней Грецией и Пелопоннесом [3, с. 209, прим. 1], однако потом, по словам Зосима, снова приступили к нападению на греческие города, особенно жестоко разграбив Коринф и Спарту (Zosim., V, 6, 4-5).

Несмотря на то, что некоторые древние авторы, упоминая данные события, также как и Зосим, говорят о готском нашествии (Claud. Rufin., II, 191; Philost., XII, 2; Hyeronym. Ep., 60, 16), не все здесь выглядит так однозначно. Тем не менее, мы согласны с профессором X. Арсе, который считает, что версии этих источников не сильно расходятся с текстом Зосима. Текст Иеронима является достаточно общим, чтобы из его содержания делать вывод о конкретных разрушениях. Отрывок же труда Филосторгия, в котором упоминается о взятии и ограблении Афин, является обычным стереотипным рассказом о взятии городов неприятелем. Даже Клавдиан, несмотря на то, что пишет о взятых в плен женщинах, нигде не говорит о взятии и разграблении готами Афин [20, р. 58-59]. Если к этому добавить отчетливо выраженное в тексте Зосима стремление готов не к повальному грабежу, а к переговорному процессу с жителями греческих городов, то можно сделать вывод о наличии какой-то определенной цели у Алариха в Греции, не связанной с захватом людей и добычи. Исходя из сложившейся к этому времени сложной ситуации с готами, можно допустить, что федераты были намерены осесть в Греции и в дальнейшем проживать здесь за счет местного населения [22, р. 115]. Вот почему варвары могли изначально отправиться в Грецию по согласованию с Евтропием. Возможно, в этом и заключается причина такого противоречивого поведения Алариха в Греции, которое свидетельствует, что готский рикс все еще не терял надежду занять высокую воинскую должность в римской армии $[39$, p. 57].

В этой связи трудно не согласиться с Йеном Хьюджесом, что Аларих в такой ситуации просто не мог заниматься истреблением и грабежом населения Греции [15, с. 147]. Может быть, тенденциозно поданные сведения о жестокости готов в указанных выше источниках, и в первую очередь у Зосима, появились не случайно и совсем по другой причине? Здесь вполне могли сыграть свою роль факторы, не имеющие прямого отношения к событиям 397 г. в Греции. Например, довольно серьезное обострение противоречий между язычеством и христианством, которое к концу IV в. достигло наивысшей степени. Во всяком случае, чудесное вмешательство Афины и Ахилла в спасение греков, недвусмысленно указывает на появление в это время необходимости формирования достойного языческого ответа на притязания христианских сверхъестественных защитников [20, р. 55]. Уходящий в прошлое мир отживающего язычества, в данный период активно искал точку опоры, что и порождало интенсивное рождение всякого рода легенд [12, с. 47]. Это вполне могло стать причиной искажения любых исторических фактов с целью убедительной демонстрации могущества воссозданного языческого пантеона уже со своими божественными защитниками [20, р. 55]. Вот почему, несмотря на уверенность многих ученых в реальном нападении Алариха на Грецию [28, р. 167; 27, р. 168; 41, р. 271], вероятней всего в том виде, как эти события представлены в источниках, их никогда не было.

Во всяком случае, сомнения по этому поводу высказывались уже давно [30, р. 35; 26, р. 119]. Новейшие археологические исследования в Греции, недавно проанализированные профессором Х. Арсе, показали, что эти сомнения были не напрасны. С одной стороны, обнаруженные в стене Агоры построенной около 400 г. многочисленные элементы разрушенного и сожженного храма, на первый взгляд, действительно указывают на Алариха, враждебные действия которого, якобы и стали причиной гибели здания в 396 г. [37, р. 263-264]. Однако, с другой стороны, выявленные здесь же остатки сожженной статуи богини сделанной из золота и слоновой кости, явно свидетельствуют против готов, так как уничтожение варварами золотых предметов во время грабежа, выглядит совершенно невозможным [20, р. 59-60]. В этой связи, учитывая также, что другие здания акрополя не пострадали, действительно можно предположить, что причиной пожара могла быть молния, банальная халатность [35, р. 218], и даже стихийное бедствие, затронувшее в тот момент Грецию [20, р. 66]. Таким образом, несмотря на вероятность захвата готами в Греции ряда городов, очевидно, что никакого истребления местного населения варварами здесь не было [20, р. 61].

Нам представляется, что ближе всех к решению этой проблемы, подошел Йен Хьюджес, по мнению которого, действия варваров в Греции в 396-397 гг. больше походили на тактику готов в 378-382 гг. в аналогичных условиях. Она заключалась в демонстрации угрозы нападения городам с целью обеспечения варваров продовольствием $[15$, с. 147]. Все это вновь возвращает нас к версии о возможном заключении некой договоренности между Евтропием и Аларихом. По-видимому, исходя из нее, готы стали претендовать на земли в Греции, возможно даже на полуострове Пелопонессе [20, р.67], куда они продвинулись, явно исходя из своих интересов. Однако резкий отпор и проявление массового недовольства местного 
греческого населения от перспектив такого соседства, похоже, привели к пересмотру первоначальных планов по расселению варваров на территории империи. Источники не сохранили сведений, куда теперь было решено отправить беспокойных федератов. Тем не менее, не исключено, что именно это решение и стало основным провоцирующим фактором нападения Стилихона на Грецию. Косвенно на это указывает назначение в конце 396 г. или в начале 397 г. на должность praefectus praetorio Italiae, Africae et Illyrici Теодора (Cod. Th., 11.16.21; 11.30.58) [15, с. 144]. То есть непосредственно перед переброской западноримских войск в Грецию с целью оперативного перехвата и окружения готов, Стилихон сосредоточил внимание на укреплении своей части Илирика. Все это может означать, что главным провоцирующим фактором похода Стилихона на Грецию, стала дошедшая до Запада информация, как о достигнутом соглашении Евтропия с Аларихом, так и о полученном готами разрешении на расселении в Иллирике.

В научной литературе обычно называют достаточно разные причины этой новой войны Стилихона с Аларихом. Самой распространенной версией является якобы возникшая необходимость в защите Стилихоном Римской империи от грабежей готов и возможность одновременного оказания давления на восточное правительство [4, с. 203; 15, с. 151]. При этом иногда оговаривается, что если Стилихон действительно представлял себя защитником двух императоров, то его не надо было специально приглашать на Восток, чтобы провести военную операцию против мятежников [20, с. 67]. Также говоря о причинах похода Стилихона на Грецию, нередко называют желание правителя Запада захватить территорию на Востоке [32, р. 200], указывают на стремление Стилихона вернуть готского рикса или, по крайней мере, его воинов, под свое командование [21, р. 214], а также, обращают внимание на намерение наделить Алариха большей ответственностью перед империей и гарантировать ему, что никогда он больше не будет отчужден от нее [23, p. 124]. При этом помимо указанных, относительно широко распространенных гипотез, иногда в литературе встречаются и довольно оригинальные предположения по данному вопросу. Правда, такие версии, как правило, противоречат источникам по данному периоду. В качестве примера можно привести утверждение, что якобы пускай и без энтузиазма, но Евтропий и Аркадий добровольно согласились принять помощь Стилихона против Алариха, грабившего мирное население [6, р. 467]. Согласимся, что это маловероятно, так как для Евтропия такой шаг был равносилен самоубийству.

Таким образом, с одной стороны, практически все предложенные версии причин нападения Стилихона на Грецию, кроме последнего варианта, в той или иной степени, опираются на серьезные аргументы и доводы. Однако, с другой стороны, каждая из них по отдельно- сти, не может объяснить все нюансы сложного клубка взаимоотношений в треугольнике Стилихон - Аларих Евтропий. В этой связи, очевидно, что выявить реальную причину войны Стилихона против Алариха в 397 году, возможно только через специфику политической ситуации сложившейся к этому времени в империи и анализ конкретных действий правителя Запада в Греции. Однако здесь также необходимо обратить внимание на политику Стилихона по отношению к Востоку еще до похода на Грецию. Не вызывает сомнений, что если бы все шло по задуманному Стилихоном плану, то необходимости в таком походе не было. Именно активное противодействие Евтропия разрушило далеко идущие замыслы Стилихона и сделало невозможным относительно мирный вариант объединения двух частей Римской империи под главенством Запада. Таким образом, сорванные планы Стилихона по причине противодействия Евтропия и Алариха, стали основным определяющим фактором его действий на Востоке. Таким образом, поход на Грецию был направлен, в первую очередь, на исправление ситуации в наиболее проблемных звеньях многоходового плана Стилихона по объединению империи. Данные проблемные области достаточно уверенно определяются исходя из четко ограниченных двух сфер деятельности Стилихона. Это собственно воинская операция против готов в Греции и одновременная пропагандистская кампания по масштабному очернению образа нового фаворита Аркадия (Claud. Eutrop., I-II), который удивительным образом, «от раба-евнуха поднялся до высот власти» (Philost., Xl, 4). Следовательно, вся восточная политика Стилихона была направлена, как против Алариха, так и против Евтропия. Заключение же договора между Евтропием и Аларихом, предусматривающее переселение готов в Иллирик, сделало военное решение назревшего конфликта просто неизбежным. Поэтому конечная цель пребывания Стилихона в Греции, по-видимому, заключалась в возвращении готов под свое командование (с непредсказуемой судьбой Алариха), а также в устранении от власти могущественного евнуха. Таким образом, у фактического правителя Запада, вновь появлялся шанс достичь своих амбициозных притязаний на власть над двумя частями Римской империи.

Исходя из вышесказанного, предположение о Константинополе, как о конечной цели греческого похода Стилихона [39, р. 157], представляется вполне вероятным и даже логичным, особенно после победоносного урегулирования готского вопроса. Несмотря на критику [15, с. 150, прим. 34], такой план хорошо объясняет, почему на этот раз доставить свои войска на Восток, Стилихон решил именно морем. Дело в том, что использование Стилихоном флота для быстрого перемещения своих легионов, действительно было необходимо, если после греческой кампании планировалась их переброска в Константинополь. 
Дождавшись смерти своего видного сторонника, тяжело больного епископа Амвросия (Paulinus Vita Amb., 45), скорее всего, в самом начале апреля 397 года, Стилихон переправляет по морю свою армию в Коринф [15, с. 150-151]. Вскоре, после этого отступившие готы оказываются заблокированными на горе Фолоэ в Аркадии (Zosim., V, 7, 2). [27, p. 86]. Такое положение дел, предсказуемо вызывает огромную озабоченность в Константинополе. По-видимому, Евтропий начинает хорошо осознавать опасность военных действий между Стилихоном и Аларихом. Дело в том, что сражение между этими двумя фактически римскими армиями, могло повредить его переговорам с Аларихом и сорвать наметившееся возвращение готов в римскую военную структуру на Востоке. Более того, Евтропий мог задуматься и о своей дальнейшей незавидной судьбе, которая неизбежно ждала бы его после победы Стилихона над Аларихом. Поэтому сложившаяся ситуация стала для Евтропия, не столько временем выбора между союзом с Аларихом или Стилихоном [26, р. 115-121; 38, р. 166-168; 24, р. 158-163; 43, р. 27-38], сколько вопросом жизни и смерти. Не удивительно поэтому, что Евтропий срочно добился от императора издания приказа Стилихону о его немедленном возвращении домой на Запад, а на случай, если же он надумает отправиться в Константинополь, объявил его еще и врагом государства hostis publicus (Claud. IV Cons. Hon., 479f; De Bello Get., 513-517) [15, c. 153-154].

В этой связи, не совсем понятной выглядит ситуация с упомянутым Клавдианом сражением между Стилихоном и Аларихом (Claud. IV Cons. Hon., 479f), ведь отступление готов не совсем обязательно должно было иметь отношение к военному поражению варваров. Йен Хьюджес считает, что это сражение могло состояться уже после получения Стилихоном приказа о возвращении в Италию. То есть Стилихон принципиально захотел покорить готов до своего ухода на Запад и тем самым вызвал на себя гнев Константинополя. Только после этого он был объявлен врагом государства, что в свою очередь, позволило готам ускользнуть [15, с. 153-154]. Однако такая версия происшедших событий расходится с данными источников. После того, как Аларих оказался загнанным на горе Фолоэ, он уже был не в состоянии воевать со Стилихоном и только искал пути отступления, в том числе и через подкуп римской армии золотом (Claud. De Bello Get., 87-88) [27, p. 170-171]. Вряд ли в такой ситуации между противоборствующими силами проходили еще и активные боевые действия с большим количеством пострадавших. Скорее всего, в это время Стилихон, не то чтобы напрямую вступил в союз с Аларихом, как считают некоторые ученые [28, р. 143; 27, р. 86, 172; 4, с. 203-204], но, похоже, обдуманно решил предоставить Алариху возможность спастись. Возможно, тем самым он оставлял себе на вооружение один из самых сильных аргументов, предназначенных для очернения образа Евтропия в глазах римского общества. При этом необходимо исходить из того, что именно уничтожение фактического правителя Востока, продолжало оставаться для Стилихона важнейшей стратегической задачей. Тем более теперь, когда ему вновь приходилось отступать, не достигнув своей поставленной цели, а в дальнейшем пытаться решить возникшую проблему, как и ранее, излюбленным радикальным способом.

Положение усугублялось еще и тем, что теперь подобно готам, ушедшим в Эпир (Zosim., V, 7, 2), западная римская армия отходила к побережью к своим кораблям, через враждебно настроенное местное население, не желающее отдавать врагам государства продовольствие. По этой причине его теперь приходилось изымать силой, со всеми вытекающими последствиями [15, с. 155]. Однако, версия Зосима, резко отрицательно относившегося к Стилихону [16, с. 70], что именно падение дисциплины в армии привело его к поражению (Zosim., V, 7, 2), не нашла поддержки у исследователей [42, р. 262; 31, р. 36]. Очевидно, что не проблема управления в войсках, а именно категорический приказ из Константинополя, как и в недалеком прошлом, вновь лишил Стилихона победы и всяких перспектив его дальнейшего пребывания на Востоке. При этом все имущество Стилихона, также было конфисковано (Claud. IV Cons. Stil., I, 297-298), а он сам, возможно был даже готов к объявлению ему войны [47, р. 149; 39, р. 397; 15, с. 154]. Конечно такое неблагоприятное развертывание событий, вряд ли входило в планы Стилихона. Но, тем не менее, даже его возвращение нельзя представлять в качестве окончательного поражения. Очевидно что, как и в недавней истории с Руфином, противостояние Запада и Востока не закончилось с отходом Стилихона на Запад. Этим событием оно, безусловно, только открывало новый этап борьбы за власть в государстве.

Надо сказать, что такой очередной виток конфронтации с Западом после войны в Греции, хорошо прослеживается по ответным действиям Евтропия. Хотя в данное время Стилихон уже вернулся на Апеннинский полуостров, могущественный евнух сосредоточил все свои усилия по противоборству фактическому правителю Запада.

Во-первых, Евтропий окончательно утвердил Алариха на высокую должность magister militum per Illyricum. Приблизительно в это же время (июнь-июль 397 - 12 ноября 399 гг.) указом Аркадия praefectus praetorio Illyrici, в тот же регион, был назначен Анатолий (Cod. Th. 11.14.3; 6.28.6) $[15$, с. 144]. Таким образом, посредством такой реорганизации восточной части Иллирика, для Алариха была решена задача размещения своих людей на новой территории, скорее всего в Македонии [4, с. 205, прим. 15]. В качестве федератов готы вновь были обеспечены положенными им выплатами и самое главное, продовольствием [39, р. 59; 33, р. 205; 34, р. 57]. Кроме того, 
обращает на себя внимание и то, что Аларих со своими варварами был отправлен в самый важный и стратегический регион, пограничный с владениями Стилихона. Это означало, что Евтропий не боялся возможного сговора Алариха со Стилихоном, по причине значительной степени конфронтации между ними. По-видимому, данное обстоятельство, лучше всего обеспечивало устойчивость враждебных отношений между ними и гарантировало невозможность их объединения против Евтропия $[15$, с. 157].

Во-вторых, Евтропий окончательно сосредоточил управление восточно-римскими воинскими подразделениями в своих руках [18, s. 621-645]. Речь идет о презентальных армиях, которые в конце IV века приобрели значение самого эффективного средства борьбы за власть [5, с. 94-95]. Важнейшим событием на этом направлении деятельности Евтропия, стало его личное выступление во главе с восточной армией в поход против гуннов, напавших на территорию Малой Азии в 397 г. Всесильному евнуху участие в такой военной кампании было крайне необходимо для поднятия престижа в армейских кругах, а также с целью обеспечения себе дальнейших карьерных перспектив. Во всяком случае, не вызывает сомнений, что данная победоносная кампания явно помогла Евтропию добиться консульства в 399 г. (Marcell. Chron., 399).

В этой связи, ученые обычно не оспаривают сведения о гуннском нападении 397 г. и говорят о восточном походе Евтропия как о реальном историческом событии [7, с. $76 ; 6$, с. $486 ; 15$, с. $157 ; 46$, p. $28 ; 19$, s. $186 ; 27$, р. $125 ; 10$, c. 66]. Однако здесь сильно смущает практически полное (кроме поэмы Клавдиана) отсутствие сведений в источниках об этой войне с гуннами. Тем удивительней картина выглядит в сравнении с восточным походом гуннов в 395 году, который нашел свое отражение в целой группе различных древних сочинений [9, с. 9-16]. Правда, в хронике Бар-Эбрея, рассказ о гуннском походе датирован 397 годом, но к этой дате, варварское нашествие, вряд ли имеет какое либо отношение. Дело в том, что данное сообщение опирается на сочинения предшествующих историков и, в первую очередь, на хронику Иешу Стилита, где на самом деле рассказывается о все том же гуннском нападении 395 г. Поэтому именно к указанному году необходимо относить и сведения Бар-Эбрея [11, с. 39]. Следовательно, поэма Клавдиана, оказывается единственным источником, в котором упоминается восточный поход Евтропия 397 года, что сразу вызывает недоверие ко всей этой информации. Сомнения еще более усиливаются из-за наличия некоего двойственного подхода в описании войны Евтропия с гуннами, и без того в крайне тенденциозном тексте Клавдиана. С одной стороны поэт рисует картину, казалось бы победоносной для Евтропия военной кампании. С другой стороны, открыто намекает на хитрость евнуха, который лишь де- монстрирует свои ложные подвиги «словно с победой идет», при этом «упиваясь собой, он тщится пространны щеки распучить свои, от подвигов мнимых одышлив» (Claud. Eutrop., I, 255-260).

Предположение, что Клавдиан, полностью выдумал весь восточный поход Евтропия, вряд ли будет верным. Во всяком случае, ужасы нападений гуннов на восточные провинции, поэт явно взял исходя из реалий 395 г. Поэтому признать его поэтический рассказ абсолютным недостоверным, как это сделал О. Менхен-Гельфен [40, р. 56], нельзя. Возможно, в произведении Клавдиана нашли свое отражение отголоски, какой-то действительно реальной военной кампании Евтропия, призванной окончательно укрепить его авторитет в армейских кругах и в которой кочевники, судя по всему, сыграли строго отведенную им роль. Например, гунны в данный момент, могли не столько нападать, сколько участвовать в переговорах по заключению мира с Евтропием. Может, по большей части, именно в установлении нового союза с кочевниками и заключалась собственно победа всемогущего евнуха? Тогда понятным выглядит и обвинение Евтропия в ненастоящих, мнимых подвигах, достигнутых на фоне недавнего гуннского разорения восточных провинций.

B-третьих, похоже, Евтропий на данном этапе борьбы со Стилихоном, решает от обороны, перейти в наступление. Тем более что этому сопутствовало появление на Востоке посланников от Гильдона - правителя провинция Африка, с предложением своего выхода из под юрисдикции Рима и перехода под власть Константинополя. Вряд ли конечно это восстание, послужило непосредственной причиной возвращения Стилихона с Востока [25, р. 254]. По всей вероятности, когда гонцы Гильдона прибыли к Евтропию, Стилихон уже ушел из Греции, но это было уже не важно. Начавшийся новый виток вражды между Западом и Востоком, способствовал активизации старых конфликтов, тем более таких сложных, как в Северной Африке [15, р. 158-159]. Все это резко повышало ставки восставшего против Запада Гильдона [15, с. 160-166]. Во всяком случае, последний не ошибся в своих ожиданиях и Евтропий сразу же согласился переподчинить Востоку западную провинцию Африка. Это не только создавало угрозу снабжения зерном Рима, но и в перспективе могло было привести, на волне возникших беспорядков, к падению власти самого Стилихона [15, с. 163].

Таким образом, греческая кампания Стилихона 397 г., привела к значительной эскалации конфликта и усилению противостояния Запада и Востока. В основу же этой новой конфронтации, теперь легла разгоревшаяся борьба между Стилихоном и Евтропием, двумя фактическими правителями Римской империи. 
ЛИТЕРАТУРА

1. Богданов Д.Е. Военные компании «последнего защитника Рима» Флавия Стилихона // Научные ведомости БелГУ. Серия История, Политология. 2015. №7(204). Вып. 34. С. 53-57.

2. Богданов Д.Е. Борьба Западного и Восточного дворов Римской империи в конце IV века // Научные ведомости БелГУ. Сер. История. Политология. 2017. №22(271). Вып. 44. С. 41-45.

3. Болгов Н.Н. (ред.). Зосим. Новая История / Перевод, комментарии, указатели. Белгород: Издательство БелГУ, 2010. 344 с.

4. Вольфрам Х. 2003. СПб.: Ювента, 2003. 656 с.

5. Глушанин Е.П. Военная знать ранней Византии. Барнаул: Алт. кн. изд-во, 1991. 246 с.

6. Голдсуорти А. Падение Запада. Медленная смерть Римской империи. М.: АСТ, 2014. 733 с.

7. Козлов А.С. Борьба между политической оппозицией и правительством Византии в 395-399 гг. // Античная древность и средние века. Свердловск, 1976. Вып. 13. С. 68-82.

8. Коньков Д.С. Готы на территории Римской империи: трансформация этно-потестарной идентичности. Северск: Изд-во СТИ НИЯУ МИФИ, 2011. 151 с.

9. Манасерян Р.Л. Гунны в отношениях с Ближним Востоком и Римским Западом. Санкт-Петербург: Алейтейя, 2019. 118 с.

10. Мехамадиев Е.А. Синезий Киренский и войсковое подразделение «Уннигарды»: к вопросу о положении готов и гуннов в западной Римской империи в последней четверти IV в. // Вестник Нижегородского университета им. Н.И. Лобачевского. - 2015. - №1. - С. $78-86$.

11. Пигулевская Н.В. Сирийские источники по истории народов СССР. М.; Л.: Изд-во Академии наук СССР, 1941.170 с.

12. Сбитнева Ю.Н., Липич В.В. Конфликт отторжения: готы в Византии в конце IV в. // Научные ведомости БелГУ. Серия: История. Политология. Экономика. Информатика. 2010. №7(78). Вып. 14. С. 44-48.

13. Сиротенко В.Т. Борьба Западной Римской империи и Византии за префектуру Иллирик в 395-425 гг. и ее последствия // Античная древность и средние века. Свердловск, 1972. Вып. 8. С. 73-88.

14. Хизер П. Великие завоевания варваров. Падение Рима и рождение Европы. М.: Центрполиграф, 2016. 830 с.

15. Хьюджес Й. Стилихон. Вандал, который спас Рим. М.: Изд-во «Клио», 2017. 352 с.

16. Чекалова А.А. Запад и Восток в представлении ранневизантийских авторов // Вспомогательные исторические дисциплины. 2007. Т. XXX. С. 64-72.

17. Чекалова А.А. Сенат и сенаторская аристократия Константинополя. IV - первая половина VII века. - М.: Наука, 2010. 341 с.

18. Albert G. Stilicho und der Hunnenfeldzug des Eutropius // Chiron. 1979. Bd. 9. S. 621—645.

19. Altheim Fr. Geschichte der Hunnen. Bd. IV: Die Europäische Hunnen. Berlin: De Gruyter, 1962. $388 \mathrm{s.}$

20. Arce J. Alarico (365/370-410 A.D.) La integración frustrada. Madrid: Marcial Pons Historia, 2018. 180 p.

21. Baynes N.H. A note on Professor Bury's'History of the later Roman Empire' // The Journal of Roman Studies. 1922. Vol. 12. P. $207-229$.

22. Blockley R. C. The dynasty of Theodosius / Ed. A. Cameron, \& P. Garnsey // The Cambridge Ancient History XIII: The Late Empire, A.D. 337 - 425. Cambridge: Cambridge University Press, 1998. P. 111-137.

23. Boin D. Alaric the Goth: An Outsider's History of the Fall of Rome. New York: W. W. Norton \& Company, 2020. 272 p.

24. Burns T. Barbarians within the gates of Rome: a study of Roman military policy and the barbarians, ca. 375-425 A.D. Bloomington: Indiana University Press, 1994. $417 \mathrm{p}$.

25. Burrell E. A Re-Examination of Why Stilicho Abandoned His Pursuit of Alaric in 397 // Historia: Zeitschrift für Alte Geschichte. 2004. Vol. 53. №.2. P. $251-256$.

26. Bury J.B. History of the later Roman Empire: from the death of Theodosius I to the death of Justinian (A.D. 395 to A.D. 565). London: Macmillan, 1923. 471 p.

27. Cameron A. Claudian: Poetry and Propaganda at the Court of Honorius. Oxford: Clarendon press, 1970.508 p.

28. Demougeot E. De l'unité à la division de l'empire romain, 395-410. Paris: Adrien-Maisonneuve, 1951. 618 p.

29. Di Branco M. La città deifilosofi: Storia di Atene da Marco Aurelio a Giustiniano. Florencia: L. S. Olschki, 2006. 302 p.

30. Gregorovius F. Gesch. der Stadt Athen in mittelalter (von der zeit Justinian bis zur türkischen Eroberung), vol. I. Stuttgart: Cotta, 1889. 447 s.

31. Grumel V. L'Illyricum de la mort de Valentinien ler (375) à la mort de Stilicon (408) // Revue des études Byzantines. 1951. T IX. P. 5-46.

32. Halsall G. Barbarian Migrations and the Roman West 376-568. Cambridge: Cambridge University Press, 2007. 591 p.

33. Heather P.J. Goths and Romans, 332-489. Oxford: Clarendon Press, 1991. 378 p.

34. Heather P.J. The Goths (The Peoples of Europe). Oxford; Cambridge: Wiley-Blackwell, 1996. 358 p.

35. Holztmann B. L'Acropole d'Athènes. Monuments, cultes et histoire du sanctuaire d'Athéna Palias. Paris: Picard, 2003. 303 p.

36. Hosek R. Locorum ad historiam aevi recentioris antiquitatis classi- cae spectatium explanationes tres // Graecolatina Pragensia XX: Signum gratiae. In honorem Bohumilae Mouchovd / Acta Universitatis Carolinae philological. 2004. Vol. 20. № 2. P. 69-72.

37. Korres M., et al. Dialogues on the Acropolis. Atenas: Skai Books, 2010.512 p.

38. Kulikowski M. Rome's Gothic Wars: From the Third Century to Alaric (Key Conflicts of Classical Antiquity). Baltimore: Cambridge University Press, 2007. 225 p.

39. Liebeschuetz J.H. W.G. Barbarians and Bishops: Army, Church and State in the Age of Arcadius and Chrysostom. Oxford: Clarendon Press, 1990. 312 p.

40. Maenchen-Helfen 0. The World of the Huns: studies in their history and culture. Berkeley: University of California Press, 1973. 602 p.

41. Matthews J. Western Aristocracies and Imperial Court, AD 364-425. Oxford, Clarendon Press, 1975. 427 p.

42. Mazzarino S. La politica religiosa di Stilicone // Rendiconti dell'Istituto Lombardo. 1938. LXXI. P. 235-262. 
43. O'Flynn J. Generalissimos of the Western Roman Empire. Alberta: The University of Alberta Press, 1983. $250 \mathrm{p}$.

44. Prchlik I. Who Guided Alaric through Thermopylae? Note on Eunapius, Vitae Sophistarum, VII, 3, 5 [479 Didot] // Eirene. 2011. Vol. 47. № 1-2. P. 171-176.

45. Selvaggi R. Erfolgreiche Vertragskonzepte oder foedera incerta? Die weströmische Außenpolitik des 5. Jahrhunderts im Spiegel der römisch-germanischen

Vereinbarungen / Staats-und Universitätsbibliothek Hamburg Carl von Ossietzky. Hamburg: Hamburg University Press, 2020. $258 \mathrm{~s}$.

46. Thompson E.A. A History of Attila and the Huns. Oxford: Clarendon Press, 1948. 228 p.

47. Williams S., Friell G. Theodosius: The Empire at Bay. London: Batsford, 1994. 238 p.

\footnotetext{
( Я Ярцев Сергей Владимирович (s-yartsev@yandex.ru).
}

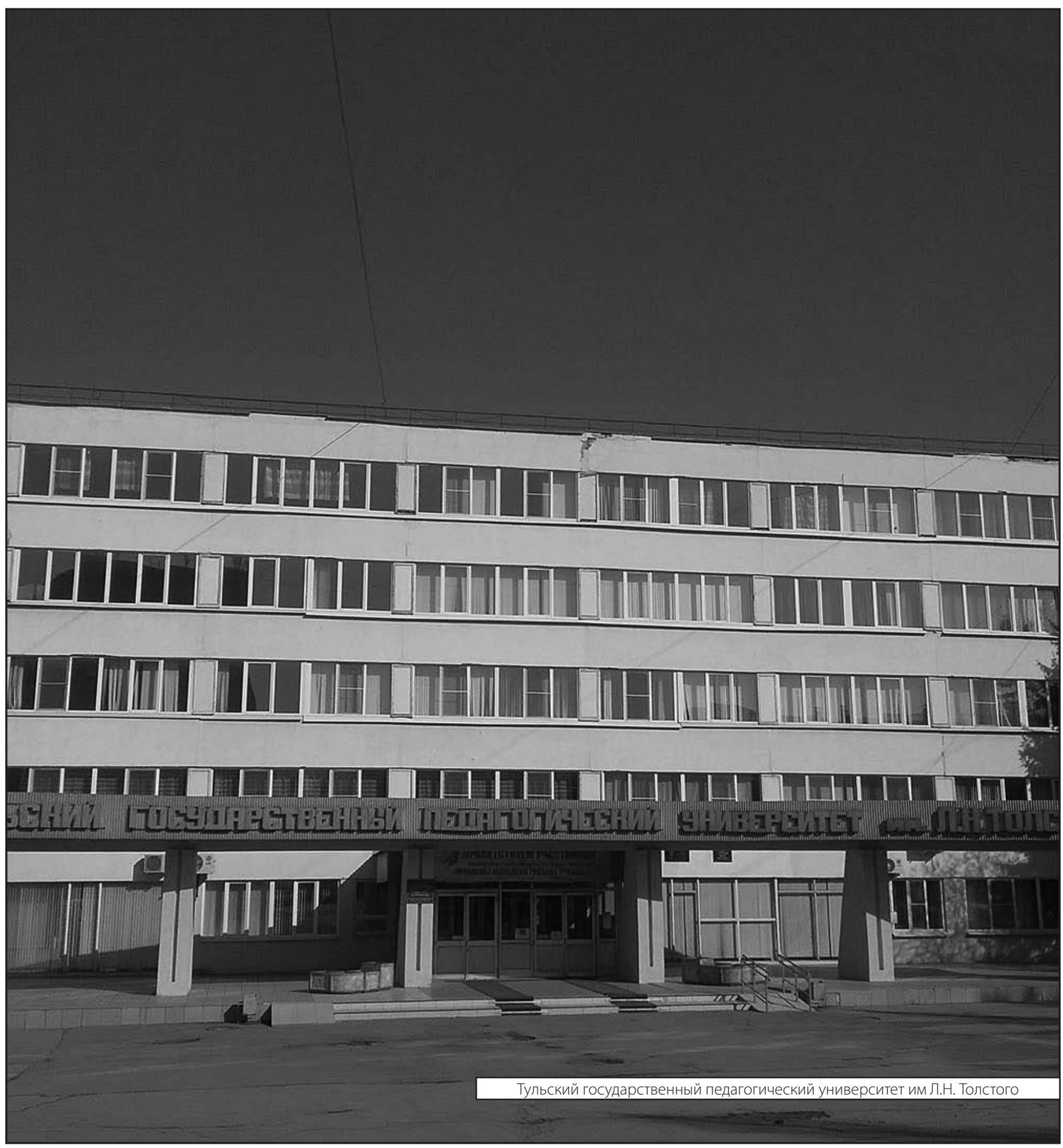

